\title{
UĞURSUZ ŞÖLEN: DEDE KORKUT'TAN J. R. R. TOLKIEN'E ORTAK BIR MOTIF
}

The Ominous Feast: A Common Motif from Dede Korkut to J. R. R. Tolkien

Doğukan ORUÇ*

\section{öz}

Birçok destanda, söylencede, halk hikâyesinde ve dinî metinde şölenlerin felâketlerle sonuçlandığı görülmektedir. Çağlar boyunca düalist kozmoloji anlayışı, zühd merkezli yaklaşım ve mitsel dil, şölene dair motifi bu yönde şekillendirmiştir. Ayrıca bu metinlerin oluşturulduğu çağlardaki belirgin güvenlik eksikliği, şölen motifi ile uğursuzluğun bir arada ele alınmasını mümkün kılmış görünmektedir. Gerek anlatıcı olarak Dede Korkut figürüne atfedilen öyküler ve gerekse Tolkien tarafından yaratılan fantastik evren çok farklı zamanlarda ve coğrafyalarda vücuda gelmişlerdir. Her iki metindeki öykülerde de doğaüstü unsurlara yer verilmiş ve adı geçen anlatılar çeşitli yönleriyle pek çok araştırmaya konu olmuştur. Oğuzların epik anlatısı olan Kitâb-ı Dedem Korkud'un ve Tolkien'in yarattığı mitolojinin (legendarium) temel yapıtaşlarından olan Silmarillion'un içinde bulunan öyküler çeşitli paralellikler taşırlar. Bu yazının amacı ise bu iki anlatının şölenler ve şölenlerden sonra yaşanan uğursuz olaylar motifi etrafında karşılaştırmalı bir biçimde okunmasıdır. Bu karşılaştırma Assmann'ın hipoleps kuramı ve Tolkien'in "Öykü Kazanı” benzetmesinden yola çıkılarak yapılmaya çalışılmıştır. Şölenlerin mitik ve arketipik kökenlere sahip bir uğursuzlukla ilişkilendirildiği görülmüştür. Bu bağlamda şölen ve şölenin uğursuzluğuna dair motifin kökenleri araştııımış, bunların her iki kitaptaki yansımaları örneklendirilmeye çalışılmıştır.

Anahtar Sözcükler: Dede Korkut, J. R. R. Tolkien, hipoleps, şölen motifi, karşılaştırmalı edebiyat.

\section{ABSTRACT}

It is seen that the feasts result in disasters in many epics, legends, folk tales, and religious texts. Throughout the ages, the dualist understanding of cosmology, the ascetical approach and the mythical language have shaped the motif of the feast in this direction. In addition, the obvious lack of security in the times when these texts were written seems to have made it possible to consider the motif of the feast and the ominousness together. Both the stories attributed to the figure of Dede Korkut as the narrator, and the stories in the fantastic universe created by Tolkien, were

\footnotetext{
* Lisans Öğrencisi. İstanbul Üniversitesi, Edebiyat Fakültesi, Tarih Bölümü, İstanbul/Türkiye. Eposta: dogukaanoruc@ogr.iu.edu.tr. ORCID ID: 0000-0003-0242-2285.
} 
formed in very different ages and geographies. The stories in these texts include supernatural elements, and the aforementioned narratives have been the subject of many studies with their various aspects. The stories in The Book of Dede Korkut, the epic narrative of Oghuzs and the stories in The Silmarillion, one of the basic building blocks of Tolkien's mythology (legendarium), have various parallels. The purpose of this article is to comparatively read these narratives around the motif of the feast and ominous events after feasts. This comparison has been attempted to base on Assmann's hypolepse theory and Tolkien's "Cauldron of Story" analogy. It has been seen that feasts are associated with ominousness that have mythical and archetypal origins. In this context, the origins of the motif of the feast and the ominousness of it have been investigated and the reflections of these in both books have been tried to exemplify.

Keywords: Dede Korkut, J. R. R. Tolkien, hypolepse, the motif of the feast, comparative literature.

\section{Hipoleptik Ufkun Genişletilmesi Bağlamında Dede Korkut ve Tolkien}

Bu yazının gayesi "şölen endişesi" diye adlandırdığım motifi birbirlerinden çok farklı zamanlarda ve çok ayrı coğrafyalarda vücuda gelmiş iki metin ekseninde incelemek: Efsanevî bir şahsiyet olarak Dede Korkut'un anlatıcı rolünü üstlendiği Kitâb-ı Dedem Korkud ve Tolkien'in kurmaca dünyasının ana metinlerinden biri olan Silmarillion. Bu karşılaştırmalı okumanın ilgili metinler etrafında şekillenmesine yönelik tercihimin birkaç sebebi var. Bu tercih aslî olarak Assmann'ın "hipoleptik ufuk" ve "hipoleptik ufkun genişletilmesi" kavramlarıyla yakından ilişkili. Bu iki kavram, bir metni öncekinin bıraktığı yerden devam ettirmek veya konuşmayı öncekinin getirdiği noktadan hareket ederek ileri götürmek anlamındaki "hypólepsis" kelimesinden türetilmiştir. Hipoleptik ufkun genişletilmesini ise Assmann "etkileşim ortamının sınırlarının ötesinde, etkileşimden uzak iletişim, yani bir önceki konuşmanın söylediğinin iki bin yıldan daha eski bir geçmişte söylenmiş olabileceği bir ilişki mekânındaki etkileşim durumu" olarak tanımlıyor (Assmann, 2015: 291). Bu etkileşimsiz iletişim hâlinin/genişletilmiş hipoleptik ufkun ilgili öykülerin esatirî anlatıcısı olarak Dede Korkut ile Tolkien arasında vaki olduğu kanısındayım. Fakat bu genişletişmiş hipoleptik ufkun nasıl mümkün olduğu açıklanmadıkça bu mistifize edilmiş bir "ozan zihni birlikteliği”ni çağrıştırmaktan kurtulamaz. Jaspers, büyük hamlelere sebep olan küresel bir etkileşimin ortaya çıkışını "eksen çağı" -veya "eksenel çağ" (Axial age)ismini verdiği bir dönemle açıklar ve ona zamansal bir hudut çizer (Jaspers, 1953). Fakat eksen çağını tanımlarken sıraladığı özellikler ve "paradigmatik kişilikler” olarak andığı tarihî figürlerin geç dönemdeki muadilleri dikkate 
alınırsa bu çağın sınırlarının, bir sınır belirlemenin anlamsızlaşacağı ölçüde, ileriye doğru genişletilmesi gerekir. Bu noktada belirtilmesi gereken şudur: Dede Korkut hikâyelerinin tam tarihini tespitten aciz kalmakla beraber var olduklarından kuşku duymamızın anlamsız kaçacağı yazı öncesi formları ve Tolkien'in kendi "legendarium"una büyük etkide bulunduğu bilinen bazı metinlerin doğuşları aynı eksen çağının hipoleptik etkileşim ağının içine düşer. Abdulla'nın alıntılayacağım paragrafı Dede Korkut Kitabı'nın oluşum evrelerini “otantik mit çağı”na değin götürerek bizi Dede Korkut hikâyeleri ile yalnızca Tolkien değil fakat çeşitli mitlere dayanarak modern destanlar söyleyen bütün yazarlar arasında bir hipoleptik ufkun varsayılabileceği kanısına yaklaştırma gücüne sahiptir:

Yazar, otantik mit çağında hiçbir kahramanını ya da yarı kahramanını, hiçbir sözünü şifrelememişti. Her şey düz ve tek anlamlıydı. Bu düzlüğün gelişe gelişe ulaştığı "olgunlaşmış" estetikpoetik-lik durumlarını yazar yaratmıyordu, onları zaman yaratıyordu. Yazarın destanda ortaya koyduğu estetikpoetik -lik öge ve araçları son derece sıradan, düzlükten bir türlü yakasını "yakasını kurtaramamış" otantik metnin kardiyogramında ancak ufki ve düz çizginin dışına çıkamamış mitolojik durgunluğun elemanlarıdır. Zaman geçtikçe onlar önce estetikpoetik-lik, sonra saf poetiklik örneklerine dönüştüler. (...) Böyle yorumlamazsak, o zaman biz Dede Korkut Kitabı'nın oluşum dönemini yapay biçimde ve oldukça küçültmüş, azaltmış oluruz (Abdulla, 2020: 206).

Hipoleptik ufuk böylece, yani Dede Korkut hikâyeleriyle aynı eksenin ürünü olarak sayabileceğimiz, kökenleri otantik mit çağına değin uzanan diğer metinlerin Tolkien tarafından okunması (yazı), bir bağlam içinde yorumlanması (çerçeve) ve problematize edilerek tekrar kurgulanmasıyla (olay) genişlemiş olur. Zannımca şölen endişesi konusunda Tolkien'in “kaldıkları yerden devam ettirdikleri” metinler ile Dede Korkut Kitabı'ndaki öyküler arasındaki benzerlik düşünülecek olursa kurmaya çalıştığımız bağın daha da güçlendirilmesi mümkündür. ${ }^{1}$ Zira Tolkien'in esin kaynaklarının Beowulf ve İskandinav destanları başta olmak üzere çeşitli destanlar (Shippey, 2005: 66-74; Carpenter, 1977: 59), "biblical" olarak adlandırılan birtakım metinler, muhtelif mitolojiler ve Jordanes'in yazdığı gibi bazı Orta Çağ

\footnotetext{
1 Örneğin, Tolkien'in oldukça etkilendiği bilinen Fin destanı Kalevala'daki Lemminkäinen'in Pohjola diyarındaki düğün şölenine gelişi (Lönnrot, 1966: 26) ile Dede Korkut hikâyesindeki öldüğü zannedilen Bamsı Beyrek’in eski eşinin düğününe (Gökyay, 1975: 77) gelişi.
} 
kronikleri (Librán-Moreno, 2011: 99-101) olduğunu biliyoruz. Benzer biçimde, Dede Korkut Kitabı'ndaki hikâyelerin organik bir ilişki içerisinde olduğu anlatılar da aralarında ortak arketiplerin bulunduğu öncül destanlar ${ }^{2}$, geçiş evresinde kaleme alınmış olması sebebiyle i̇slâmî metinler, şifahî olarak anlatılmaya devam edilen tarihî hikâye-efsanelerdir. ilâveten, her iki anlatının da aynı gelenekten doğmaları itibariyle aralarında paralellikler bulunan Semitik dinlerin kutsal kitaplarıyla bir etkileşim içinde olduğunu görürüz. Tolkien'in kendisi - "alegori”den onca hazzetmemesinin rağmına- mektuplarının birinde Yüzüklerin Efendisi'nin "özünde Hristiyan bir kitap" olduğunu yazmıştır (Tolkien, 1981: 172). Kitâb-ı Dedem Korkud ise İslâm ve Şamanizm kültürü etrafında gelişen çeşitli motiflerle süslenmiştir. ${ }^{3}$ Öte yandan, böylesi bir bağ kendi tanımı itibariyle etkileşimsiz bir iletişimi gerektirdiği için hipoleptik ufkun iki tarafında duran isimlerin aralarında zaman farkının varlığı kaçınılmazdır ve Dede Korkut Kitabı ile Tolkien'in anlatısı bu şartı karşılamakta da bir yetersizlik göstermezler.

Tolkien'in yazını hakkındaki fikirleri ve amaçladıklarının da böylesi bir hipoleptik ufku mümkün kılan etkenler arasında olduğu kanısındayım. Zira peri masalları üzerine yazdığı meşhur denemesinde "Öykü Kazanı" adını verdiği, daimî olarak kaynayan ve sürekli olarak içindekilerine eklenti yapılan ortak bir tematik çatıdan bahseder (Tolkien, 2008: 44-45). Bu Öykü Kazanı zamanında bir dolusunun içine atıldığı bir motif seçkisi gibidir ve tüm ozanlar bu kazana kepçelerini daldırarak çıkan motiflerden kurulu öyküler anlatırlar. Bu kolektif bilincin peri masalları üzerinden Tolkien-vâri bir ifadesine benzemektedir. Bu örneği destekleyecek biçimde Tolkien'in kendi yazınına yön tayin eden en önemli amaçlarından birini de gözden kaçırmamak gerekir. Shippey, Tolkien ile Wagner'i ikisinin "yüzük" anlatıları ekseninde karşılaştırdığı bir denemesinde "Tolkienci" olarak adlandırdığı bir tavra işaret etmiştir. Bu tavrı "kadim kaynaklardaki boşlukları tespit etmek ve öykülerin kendi versiyonlarını bu boşluklar üzerine yazmak" ifadeleriyle açıklar (Shippey, 2007: 112). Böylelikle Tolkien'in bir yazar olarak anlatısını inşa etme yolunda benimsediği tavır da varsaydığımız hipoleptik sürecin oluş-

\footnotetext{
${ }^{2}$ Haddizatında Muharrem Ergin, Kitâb-ı Dedem Korkud'un daha büyük bir destandan ayrılmış izlenimi verdiği kanısındadır ve onu eldeki hâliyle destan ve halk hikâyesi arasında bir yere yerleştirir (Ergin, 1997: 29). Ülken de (2017: 258) aynı kanıdadır: “(...) Oğuznâme'de ve daha sonra onun Türk ozanları tarafından söylenip derlenmiş bakiyeleri olan Dede Korkut kitabında..."

${ }^{3}$ Dede Korkut Kitabı'ndaki öykülerin "şaman kültürü çevresindeki eski havayı" taşıdıkları Xun tarafından (2000: 465) dile getirilmiştir.
} 
masına katkı sağlar. Zira o da Öykü Kazanı'na kepçe daldırmaktadır ve nasibine çıkanları kullanarak inşa ettiği öyküde öncekilerin boş bıraktıkları noktaları tamamlamak arzusundadır. Dolayısıyla iki anlatı arasında sırt verdikleri geleneklerin denk düştükleri eksen çağının yakınlığı ve anlatı türlerinin kaçınılmaz kıldığı benzerlikler sebebiyle hipoleptik bir ufuk gözlemlenebilir hâle gelir. Böylesi bir karşılaştırmalı okumayı yapmak için seçtiğim motif şölen ve onun her iki anlatıda da çeşitli felaketlerle yakından ilişkilendirilen doğasıdır. Bu minvalde yapılacak bir karşılaştırmalı okuma için öncelikle ele alınan motifin açıklanmasına yönelik bir dizi soruşturmaya girmek kaçınılmazdır.

\section{Bir Motif Olarak Şölen Endişesi}

Eğlenmek insanı korkutmuştur. Neşe, ardı sıra gelen bir hüznün ulağıdır. Çok gülenin çok ağlayacağı endişesi atalar kavillerinde bile kendine yer bulur. Nebevî öğütler fazla gülmenin gönlü karartacağı konusunda ısrarcıdır. İslâm peygamberinin tebessüm ettiği fakat hiçbir zaman kahkahayla gülmediği rivayet edilir ve diğer bütün peygamberâne vasıflarıyla birlikte bu da övülesi bir özelliği olarak zikredilir. Tanah'ta kendilerine kız verilmeyen Benyaminoğulları soylarının kurumaması için bir şölen öncesi Şilo yakınlarına tüner ve bu şölende dans eden kızları kaçırarak kendilerine eş ederler. Nitekim Tanah'ın Yeremya bölümünde Rabb'in kendisi de hayli öfkelenmesine sebep olan Bâbil'den alacağı öcü betimlerken onlara sarhoş olacakları bir şölen vereceğini söyler, tabii ki "uyanamayacakları sonsuz bir uykuya dalmaları" için. Keza Vaiz'de yas evine gitmenin, şölen evine gitmekten daha iyi olduğu söylenmiştir (Kutsal Kitap, 2002: 328, 1006, 827). Neşrî, Bilecik tekfuruyla Osman arasında bir düğün şöleni etrafında şekillenen karşılıklı entrikaları hikâye eder (1995: 97-103). Bu misalleri sayfalarca sürdürmek mümkün. Fakat bu çok büyük bir kazanım olmayacağı gibi bizi bir hataya da sürükleyebilir, bu örnekleri uzun uzadıya sıraladıktan sonra, onların çokluklarından kuvvet alarak aralarındaki farklara dikkat etmeksizin hepsini bir yere toplama hatasına. Oysa hepsi gülmenin ardından ağlamanın geleceğine ve şölenlerin emniyetsiz havasına işaret etse de aralarındaki motivasyon farklarını gözden kaçırmamak gerekir. Nihayetinde soru, insanın çok gülmekten ve gülüp eğlenmede toplumsal olarak en aşırıya vardıkları şölenlerden niçin çekindiklerine, böyle bir endişeyi duymalarına "neyin" değil fakat "nelerin" sebep olduğuna, Bergson'un deyimiyle bir toplumsal jest olarak gülmenin niçin "korku uyandırdığına" (Bergson, 2015: 22) dairdir. Bu meyanda masallarda, destanlarda, atasözlerinde, dinî metinlerde ve nihayet hem Dede Korkut Kitabı'nda hem de Tolkien'in Silmarillion'unda karşımı- 
za çıkan bu ortak korkunun, bu şölen endişesinin motivasyonel kökenlerini birkaç kategori altında toplamakla işe başlayabiliriz. ${ }^{4}$

Şölen endişesinin motivasyonel kökenleri konusunda ortaya koymak istediğim ilk kategori antik çağlardan başlayıp Orta Çağ'a kadar gücü korunagelen ve birçok farklı kültürde kendisine yer bulan "düalist anlayış". Her şeyin zıddıyla kaim olduğu ve bunların ebedî bir devridaim halinde birbirlerini takip ettikleri çok geniş bir coğrafyada kendisine yankı bulan bir görüş olarak tarih sahnesinde sıklıkla kendini gösterir. Eliade düalist anlayışa "dünyanın her yerinde ve bütün kültür düzeylerinde rastlandığı" yargısında bulunur (Eliade, 2017a: 24). Doğu irfanının hemen bütün şubeleri bu düalist kozmolojiyi çeşitli şekillerde formüle ederler. Buda'nın öğretisi dünyaya gelmekle pençesine düşülen ıstırap ile ondan ebediyen kurtuluşun simgesi olan Nirvana arasındaki ikiliği vurgular. ${ }^{5}$ Taoculuk bu düalitenin modern zamanlardaki en popüler versiyonu olan Yin-Yang ikilisini vaz eder. Zerdüşt'ün öğretisinin temelleri Ahura Mazda ve Ehrimen olarak isimlendirdiği iyilik-kötülük ikilemine dayanır. Mazdekîlik ve ona muhalif bir hareket olarak ortaya çıkan Manicilik aynı iyilik-kötülük düalitesini esas alır. Bu düalite anlayışı evrendeki kötülüğün Tanrı'yla uzlaştırılması sorununa bir cevap üretmesi gerektiği için diğer dinlerde de -fakat ılımlılaştırılarak- süregelir. Tanrı ve Şeytan gerçi iyilik ve kötülük bağlamında birbirlerinin zıddında durmaya devam ederler fakat Şeytan artık Tanrı'nın eşdeğeri bir rakip değildir, onun nizamının bir parçasıdır. Düalist anlayışın çok daha kuvvetli biçimde vurgulandığı inanç sistemleri ve felsefeler -tabiatıyla- bunu bütün evrene teşmil ederler ve bu anlayış o inançların hâkim olduğu coğrafyalarda açıktan fakat başka türden inançların yaygın olduğu coğrafyalarda ise bir kalıntı hâlinde yaşar. Augustinus'un Katolik olduktan sonra felsefî olarak Platonik düalizme yakın durmayı tercih etmesi, eserlerinde ruh ve bedenin uzlaşmaz karşıtlığını sıklıkla vurgulaması ve tarih felsefesini Tanrı'nın Şehri ile insan'ın Şehri arasındaki savaşım üzerine bina etmesi onun geçmişte uzun süre bir Manici olduğu hatırda tutulursa anlamlanabilir - inanışlar iz bırakır, bireylerde olduğu gibi toplumlarda da. ${ }^{6}$ Dolayısıyla, her şeyin zıddıyla kaim olmasının kanunlaştırıldığı bir evrende "çok gülenin çok ağlaması" kaçınılmaz bir yaz-

\footnotetext{
4 "Şölen endişesi" olarak adlandırdığım motifin anlatıların kahramanları tarafından dile getirilmediğini fakat anlatıların kendisine içkin durumda olduğunu vurgulamak isterim.

${ }^{5}$ Budacılığın Dört Yüce Hakikati: "Istırap vardır. Istırabı doğuran sebepler vardır. Istırabın sonu vardır. Istırabı sonlandıran sebepler vardır." Dört Yüce Hakikat'in bir açıklaması için bk. (Yılmaz, 2007: 116-121).

${ }^{6}$ Augustinus'un düşüncesinde Maniciliğin etkisini inceleyen bir makale için bk. (Oort, 2006).
} 
gı hâlini alır ve büyük saadetleri büyük hüzünler takip eder. Eğlence korkusunun ve şölen endişesinin ilk ve en büyük motivasyonlarından birinin dünya bilgeliklerinde kendisine uzun süre hürmet edilmiş bir kaide olarak işbu düalist kozmoloji olduğu kanısındayım. Nitekim Ülken, Dede Korkut hikâyelerinin içinde yeşerdiği Türk kozmogonisinin de esas itibariyle ikici bir yapıda olduğunu -íran merkezli inançların "mücadeleci ikilik" anlayışının aksine Türk kozmogonisinde "âhenkçi ikilik"in mevcut bulunduğunu vurgulayarak- ifade etmiştir:

Türkler, âlemi birbirinin zıddı olan fakat birbirini tamamlayan iki prensip ile izah ediyorlardı. Bunlar da Gök Tanrı ve Asra Yer idi. Hakikatte her şey bir feza (kaos) halinden ibaret iken sonra vüzuh kazandıkça gök yerden, aydınlık karanlıktan, erkek cevher dişi cevherden ayrılmış ve birbirine tamamıyla zıt olan bu kuvvetlerin tekrar birleşmesinden "kişi”, yani ilk insan vücut bulmuştur (Ülken, 2017: 236).

Şölen endişesinin oluşumuna katkı sağlayanlar arasında sayılması gereken bir diğer başlık onun "mitik kökenleri”dir. Zaten şölen ile esatir, ritüel ile mit arasında çok sıkı bir bağ vardır. Eliade'nin belirttiği gibi, kökenini anlatan mitin bilinmediği ritüel yerine getirilemez (Eliade, 2001: 27). Dolayısıyla şölenleri mitlerin çocukları sayabiliriz. Şölen, mitlerde haber verilenlerin tekrarlanarak yeniden yaratılması amacına yöneliktir: "Şölen, dünyayı yaratan mitolojik olayın ataların gücü (düşlerin ezelî ataları) yoluyla zamanın akışından kurtularak, bu anda yaşanmasıdır” (Campbell, 1995: 182). Böylece onun niçin korkutucu ve endişe verici olduğunu da kavramamız kolaylaşır. Çünkü şölenin atası olan ritüel mitlerde anlatılan doğaüstü olayların şimdiki ana getirilmesi amacıyla doğmuştur ve doğal bir yaratık olan insanın aklı doğaüstü karşısında korkar, hayrete kapılır, "tedhiş”e düşer. Kutsal olanın, tam da kutsal olduğu için, akıl tarafından ihata edilememesi ve insanın bütün düşünce dizgisini yerinden oynatıcı vasıfları bütün bir söylenceler âleminde mükerreren karşımıza çıkar. Kutsal olan görkemlidir, arzulanmaya değer olandır, yücedir fakat bütün bu vasıflarıyla birlikte korkutucudur. İnsanın kutsal ile temasındaki bu tehlike motifi birçok metinde karşımıza çıkar. Örneğin, Tanrı ile Musa'nın konuşması bu haşyete güzel bir örnek teşkil eder. Bu konuşma sırasında Rab, Musa'ya "Yüzümü görmene izin veremem. Çünkü yüzümü gören yaşayamaz.” (Kutsal Kitap, 2002: 111) der ve yalnızca sırtını görmesine müsaade eder. Kur'an'da ise Musa, Tanrı'nın dağa tecellisi karşısında bayılıp düşer (Ateş, 1996: 166). Sufizmin Tanrı'yla insan arasında yetmiş bin perde olduğuna dair inanışının (Burckhardt, 2017: 154) kökenleri 
tanrısal tecellinin bu anlatılarında aranabilir. Bu tecellilerin arkaik benzerlerine de sahibiz. Akhalıların Truva Savaşı esnasında karşı karşıya kaldıkları Zeus'un tecellisini Homeros şu şekilde anlatır:

O zaman Kronosoğlu aldı eline,

ışın saçan, püsküllü kalkanı,

kapladı İda dağını bulutlarla,

gürledi, şimşek çaktı, sarstı dağı,

zaferi Troyalılara verdi, püskürttü Akhaları (Homeros, 1975: 435-436).

Kutsalın tecellisi karşısında insanın düştüğü duruma bu yazının başlığında yer alan iki anlatının içerdiği öykülerde de rastlarız: Korkut'un Deli Dumrul'u Azrail'i gördüğünde bir hayli dehşete düştüğü gibi Tolkien'in Tuor'u da Ulmo karşısında belirdiği zaman büyük bir heyecana kapılmıştır. Böyle bir altyapıya sahip olan mitlerin aktardıkları şölenlerde de birtakım belâlar eksik olmaz. Bir Sümer miti insanın yaratılışı kutlamak amacıyla Enki'nin düzenlediği şölenden bahseder. Tanrı Enki ve Tanrıça Ninmah bu şölende sarhoş olur ve deniz dibinin yüzeyinden çıkardıkları killer ile biçimsiz şeyler yaratırlar (Kramer, 2016: 199). Böylece şölen Tanrıların yaratımını bile baltalamayı başarmıştır. Malenezya mitleri yeni yıl şölenlerinde hastalığın ve ölümün olmayacağı bir dünyanın kutlanmasını gerektirirken bunun gerçekleşmesi için öncül konumunda olan bir dizi kozmik felaketin haberini de verirler (Eliade, 2001: 91). Keza bir Batı Seram miti, şölen esnasında başkalarının kıskançlığından ötürü kuyuya atılarak öldürülen yüce bakirelerden Hainuwele'yi öyküler (Campbell, 1995: 177). Dolayısıyla, mitlerin kendilerine özgü yapıları ve şölenin onun bağrından kopup gelmesi ele aldığımız endişeyi beslemişe benzemektedir. Mitlerin insan zihninin şekillenişindeki başat rolleri ve kolektif bilince etkide bulunan arketipleri kullanma biçimleri düşünülecek olursa bu kategori daha rahat anlamlandırılabilir.

Belirtmek istediğim diğer bir motivasyon kategorisi şu: Her inanç sisteminde kendini belli oranda gösteren "zühd merkezli yaklaşım”. Sözün burasında dinlerin ortak bir tanımının yapılmasında yaşanan bir dizi problemi hatırlamak gerek. Dinlerin bir emir-nehiy zinciri emretmesi gerekmez, zira şeriatsız dinler vardır; tanrı sayısında mutabık kalmadıkları ortadadır, ruh veya ahiret gibi birtakım ortak simgeleri kullanmak zorunlulukları da yoktur çünkü ortada Budizm gibi açıkça ruh fikrini reddeden ve teolojisi tümüyle negatif olduğu için bir Tanrı bile vaz etmeyen dinler, Hinduizm gibi reenkarnasyoncu inanışlar mevcuttur. Bu sorunun aşılması yine negatif olarak inşa edilecek bir cevapla bir nebze mümkün hâle gelir: Din, "dünyevi” olmayana yönelik öğretidir. Bir nesne "kendisinden farklı bir şey olduğu ölçüde" kut- 
sallığa eriştiği gibi (Eliade, 2017b: 39) bir öğreti de "dünyevî olandan farklı bir şey olduğu ölçüde" dindir. Din bazı dünyevi kaideler bildirse bile esas amacı dünya yaşamına ilişkin değildir, ondan daha yüce bir tür hayatın varlığına dayanır. Bu da her inançta değişkenlik göstermekle beraber "zühd" diye anılan tavra yönelik bir eğilimin doğmasına sebep olur. Dünya kendisinden daha kıymetli bir şeyin varlığı sebebiyle ikincilleştiğinden ötürü ondan el ayak çekmek bir erdem olarak kabul görür. Onun zevklerini horlayıcı zühd, doğal olarak gülüp eğlenmekte bir tehlike, en iyi intimalle bir yararsızlık sezer ve şölene katılanların başına gelen korkunç olayları tasvir ettiğinde dünyevî eğlencelere dalmanın olumsuz sonuçlarına dair ikazda bulunma niyetindedir. Gülmenin ve bu bağlamda eğlencenin zemmedildiği metinlerin dinî olanlarının çoğunda rastladığımız bu zahidâne tutumdur. Örneğin Sanders, gülmenin tarihini incelediği yapıtında Hristiyan asketizminin dünyanın maddiliğine karşı zahidâne bir protest bir tutum sergileyerek gülmeyi Tanrı'yı ve öte-dünyayı unutturacağı gerekçesiyle kınadığını belirtmiştir (Sanders, 2001: 154). Öte yandan dinlerinde zühd belirtisi olmayan toplumlarda da başka bir sebepten ötürü benzer bir tavrı görebiliriz. Eski Yunan'ın "kaygıya olduğu kadar arzuya da sınır koymayı amaçlayan" (ComteSponville, 2004: 46) büyük erdemi itidal/ölçülülük bu tavrın iyi bir örneği sayılabilir. Eski Yunan medeniyetinin en kıymet verdiği erdemlerden biri olan bu itidal anlayışının, gülmekte aşııığa gidilmesinin yerilmesiyle sonuçlandığı (Sanders, 2001: 112-114) açıktır.

Zikretmek istediğim dördüncü ve son kategori ise dünyanın gözle görülür tekinsizliği karşısında hissedilen "güvenlik eksikliği”dir. Bu, şölen endişesinin en dünyevî temelli motivasyonudur. Zira şölen büyük ölçüde dikkat eksikliğiyle eşdeğerdir. Temel amacı rahatlamak olduğu için kimsenin teyakkuzda olmadığı bir ortamın doğuşuna sebep verir. Şölen, aslî insanî endişenin, yani hayatta kalmanın ötesinde ondan muvakkaten de olsa zevk almak için düzenlenir. Eğlencenin insanı kendine çeken yapısı nedeniyle etraf gözlenmez, tehlikeler göz ardı edilir çünkü endişe ve beklenti neşenin kösteklenmesine yol açar. Dolayısıyla şölen bir bakıma "saldırıya açık olmak”la aynı anlamdadır. Benyaminoğulları'na bir kaleyi zaptedip içindeki kızları kaçırmaları değil fakat şölen yapan halkın kızlarını kaçırmaları bu yüzden tavsiye edilmiştir. Rahatlamak ve eğlenmek güvenlikten feragati gerektirir ve bir şölenin rahatlayıp eğlenmek imkânından mahrum kalan yegâne misafirleri -varsa- şölen alanının nöbetçileridir. Yazının başında değindiğim Neşrî̀nin "Hikâyet-i feth-i Bilecik" anlatısı şölenin entrikalar için mümbit bir saha olarak görüldüğünü mükemmelen ifade eder. Hikâye, Bilecik tekfuru- 
nun düğün vesilesiyle Osman'ı çağırmasıyla başlar fakat bu bir entrikadan ibarettir. Osman, yarenleri ve ailesiyle düğüne gelince onları öldürecektir:

Bilecük tekvur'ı dahi eytdi: "Yakında biz dahi düğün iderüz. Kadem rencîde kılasuz. Müşerref olavuz." didi. Osman dahi el başa urub "Hoş ola." didi. Ammâ tekvur'ın garazı düğün bahânesine getürdüb tutub helâk etmekdi (Neşrî, 1995: 97).

Oysa Osman ve çevresi tekfurun entrikasından haberdar oldukları için çoktan misilleme kabilinden bir karşı-entrika planlamışlardır. Osman, "Bizüm halkımuz sahraya öğrenmişlerdür. Bilecük tar yirdür. Düğüni anda itmesinler bir gince yerde itsünler." şeklinde bir mazeret bildirerek düğün şöleninin Bilecik kalesi içinde değil fakat dışındaki bir kırda yapılmasını sağlamış olur. Böylece herkesin düğüne iştirakiyle Bilecik kalesi savunmasız kalacaktır.

Yine ol minval üzere bu mehhâreleri öküz katarlariyle gice karanulığında hisara givürdüler. Bir yirde kodılar. Çünkü bunlar bu hiyle ile kal'aya girdiler, fi'l-hal o gice yükleründen yalın kılıç ellerinde, cümle müsellah yire dökilüb kapuya seğirdişüb derbânları tepelediler. Hisarda adem hod az kalmışdı. Cümle düğüne gitmişlerdi. Bunlar hisarı feth itdiler (Neşrî, 1995: 101).

Görüldüğü üzere, tarihle efsanenin zaman zaman birleştiği bir anlatı olarak Neşrî'nin "Hikâyet-i feth-i Bilecik"i, düğün şölenini düşmanını savunmasız hâlde ele geçirmek için kullanmak isteyen bir Bizans tekfuru ile aynı şölenden tekfurun kalesini fethetmek için istifade eden bir Türk beyinin karşılıklı hilelerinden örülüdür. Neşrî’nin anlatısının kahramanları Bilecik tekfurunun kızının düğününü en başından itibaren bir entrika alanı olarak görürler ve hikâye boyunca yaşanan her şey varlığını bu şölene borçludur. Böylece 15. yüzyılın son yıllarında üretilmiş bir metnin şölen endişesinin güvenlik eksikliğine dayanan motivasyonel kategorisine uygun biçimde şekillendiğini görüyoruz.

Böylelikle elimizde kutsal metinlerle doğrudan ve dolaylı biçimde etkileşim hâlinde olduğu konusunda şüphelenmemizin yersiz kaçacağı bütün anlatılarda tekrar edilegelen bu şölen endişesinin kökenleri konusunda kabataslak fakat iş görmekten âciz olmadığına inandığım bir dörtlü kategori elde etmiş oluyoruz: Düalist anlayış, mitik kökenler, zühd merkezli yaklaşım ve güvenlik eksikliği. Bu dört başlı motivasyon metinlerin yazılış amaçlarına göre şölen endişesinin ortaya çıktığı satırlara sinmiştir. Gördüğümüz üzere bir tarih kroniği, baskın yapılan şenliği anlatırken elbette güvenlik eksikliğinden hareket etmektedir. Baskın yapılan bir şenliği anlatan dinî bir metin ya o 
şenliğin kendisinde gelişinin kaçınılmaz olduğu felâketi sezer ya da şenliğin kendisini dünyaya ilişkin bir gaflet eseri olarak gördüğü için onu felaketle sonlandırır. Mit kökenli kutlamalar insanı kutsalın yönlendirmesiyle "başlangıçta" olanı "şimdiye" taşımayı amaçladığı için daima bir dehşeti beraberinde taşır. Fakat şenliğin tehlikesi, baskına uğraması, şölen esnasında veya sonrasında birtakım kötü olayların yaşanması ortak bir motif olarak karşımıza çıkmaya devam eder.

Öte yandan, şölenin bu uzun çağlar boyunca yalnızca korkutucu, tedirgin edici, karamsar bir biçimde algılanmadığının da vurgulanması gerekir. Kuşkusuz, bu türden katı bir yaklaşım bahsettiğimiz dört motivasyonel unsurun da yaygın olarak görüldüğü toplumlarda doğal olarak şölenlerinin kamusal olarak reddine, hiç değilse belli ölçüde marjinalleştirilmesine yol açardı. Oysa şölenler, bütün bu bahsedilen dezavantajları çağrıştırmasına rağmen Antik ve Orta Çağlar boyunca en önemli kamusal etkinliklerden biri olmayı sürdürmüşlerdir. Elias'ın ifadesiyle (2017: 143) yemek ve içmek için bir araya toplanma eylemi "o dönemde (...) insanlar arasındaki eğlence biçimlerinin en önemlisi"dir. En başta dinsel hayatın kendisi çeşitli bayramlar ve yortular dolayısıyla şölenler düzenlenmesini mümkün kılmakta, hatta talep etmektedir. Bir diğer nokta, Orta Çağ insanları için şölenin oynadığı işlevsel roldür. Bahtin, Orta Çağ insanının "karnavalesk" olarak adlandırdığı gülme biçiminin ana mekânı olan şölenler aracılığıyla "krizlerle ilgilendiğini” (Bahtin, 2001: 244) belirtir. Fakat şölenin topluma birikmiş gerginliğini atması konusunda yardımcı olması onun yine de olumsuz bir şekilde tasvir edilmesini engellemez. Nihayetinde şölen "savunusu" yapılması gereken bir şey olarak görülmüş ve Paris'teki ilahiyatçılar bu savunuyu şölenin "çılgınlığa izin vermek" olduğunu vurgulayarak yapmak zorunda kalmışlardır (Bahtin, 2005: 103). Gerçekten de topluca eğlenilen şölenlerde "kuralları, yasaları zorlayan bir yan" mevcuttu (Vigarello, 1996: 50). Nitekim şölenler insanların bir araya gelmesine -Osmanlı bürokrasi dilinde "tecemmu"larınayol açtıkları için bu sefer bir motif olarak değil, "potansiyel bozguncu" (Reinkowski, 2017: 236) bir karakter taşıdıkları şüphesiyle gerekçelendirilen bir devlet güvenliği problemi olarak otoriteleri endişeye sürüklemekteydi.

\section{Kitâb - I Dedem Korkud'da ve Silmarillion'da Şölenler}

Tolkien'in anlatısı ile Dede Korkut hikâyeleri arasındaki genişletilmiş hipoleptik ufkun, şölen endişesi motifi üzerinden ele alınması noktasında elimizde yeterince veri mevcuttur. Zira Kitâb-ı Dedem Korkud'da daha sıklıkla fakat Tolkien'in eserlerinde de azımsanmayacak ölçüde şölen düzenlendiğini görürüz. Dede Korkut hikâyelerinin hemen hepsinde Oğuzların bir hayli 
gelişkin "toy"larından bahsedilmektedir. Nitekim toy anlatıları konusunda gelişkin bir kültürün Oğuzlarda bulunduğu açıktır. Örneğin Oğuz Kağan destanının Reşidüddin versiyonunda şölen yine bir entrikaya ve Oğuz'un babası tarafından öldürülmesinin kararlaştırılmasına yol açar:

Bir gün Oğuz bütün yakınları ve dostları ile ava gitmiş̧i. Babası kâfir Kara Han bu arada bir toy tertip etti. (...) Bu iki gelin içlerini dökmek için böyle bir fırsat bekliyorlardı ve şimdi tam sırası olduğunu gördüler. Kinle ve düşmanlıkla dediler ki "Oğuz bizi tek bir Tanrı'ya inanıp ona ibadet etmeye davet etti. Biz böyle bir Tanrı tanımıyoruz dedik. O buna kızarak bizden uzaklaştı." (...) Kara Han öfkelendi ve kinle doldu. Hemen o zaman kardeşlerini ve akrabalarını toplayıp onlara dedi ki: "Oğlum Oğuz küçüklüğünde mes'ud, talihli ve padişahlığa istidatlı idi. Şimdi işitiyorum ki kendi dininden dönmüş ve başka bir tanrı seçmiş. Bu çocuğun bize ve mabudumuza ihanet edip onu küçümsemesi rezaletine nasıl katlanabiliriz?” Kengeş ederek Oğuz'u öldürmeye karar verdiler (Togan, 1982: 18-19).

Toy kültürünün gelişkin olduğunu böylece anladığımız Oğuz boylarının bir söylencesi olarak Dede Korkut hikâyelerinin içinde sıklıkla şölenlerin geçtiği anlatılar olduğu ortadadır. Öyle ki meşhur on iki hikâyenin dokuzunda çeşitli şekillerdeki şölenlere rast gelinmektedir. Açılış hikâyesinin ilk satırlarında Bayındır Han'ın yılda bir kez düzenlediği büyük şölenden bahsedilir, ikinci hikâyede Salur Kazan ve beylerini bir şölen sofrasında görürüz, bir sonraki hikâyede Banı Çiçek'in Bamsı Beyrek'in öldüğü zannedilmesi üzerine Yalancıoğlu Yaltacuk ile düğününün şöleni karşımıza çıkar. Bunları Kazan Bey'in şöleni, Deli Dumrul'un kırk yiğitle paylaştığı şölen sofrası, Kanturalı'nın Selcen Hatun ile şölen ziyafeti, "bin yerde döşeli ipek halı seccadeli şenlik”, yedi gün yedi gece süren kutlama şöleni ve nihayet Salur Kazan'a düşman olmaya karar vermiş bazı Oğuz beylerinin düzenledikleri şölen takip eder (Gökyay, 1975: 1, 21, 77, 94, 123, 149, 188, 236, 239). Bu dokuz şölenden çoğunun birtakım olumsuz durumlara sebep olduğunu ya da kötü niyetlerle düzenlendiklerini görmemiz de mümkündür. Salur Kazan'ın şöleni obasının esir alınmasına, Deli Dumrul'un şöleni Azrail tarafından baskın yemesine, Kanturalı'nın Selcen Hatun ile kurduğu sofra büyük bir baskına yol açar. Öte yandan Banı Çiçek'in Yalancıoğlu Yaltacuk ile düğün şöleni Bamsı Beyrek'in öldüğü yalanı üstüne inşa edilmiştir ve büyük bir entrikayı içinde barındırır. Aruz Koca'nın Dış Oğuz beyleriyle birlikte yaptığı şölen ise Kazan Han'a karşı bir ihanet birlikteliğinin kurulması amacıyla düzenlenmiştir ve bu şölende 
alınan kararlar Aruz'un ölümüne, diğer Dış Oğuz beylerinin ise pişmanlığına sebep olmuştur.

Buna mukabil, Tolkien'in yaratıcısı olduğu evrende de pek çok kutlamaya rast gelinir. Örneğin Bitmemiş Öyküler'de gördüğümüz kadarıyla Númenor halkı senede üç defa olmak üzere Eru'ya şükranlarını sunmak için kralları önderliğinde bir çeşit törene iştirak ederler. Bunlar yeni yılın başlaması şerefine düzenlenen "Erukyermë", yaz ortasındaki "Erulaitalë" ve sonbaharın bitmeye yakın olduğu dönemde düzenlenen "Eruhantalë" törenleridir (Tolkien, 2020a: 279). Keza Silmarillion'dan Gondolin halkının "Güneşin Kapıları" adını verdikleri büyük bir şenlik tertip ettiklerini öğrenmekteyiz (Tolkien, 2020b: 505). Yine Tolkien, Noldor Kralı Fingolfin'in düzenlediği, Beleriand Elflerini bir araya getirmeyi amaçlayan ve "Yeniden Birleşme Şöleni" manasına gelen "Mereth-Aderthad" isimli bir şölenin yapıldığı da yazıyor (Tolkien, 2020b: 245). Cücelere mahsus bir bayram olarak “Durin Günü”nden de bahsedilmektedir. Bu gün Cücelerin yeni yılının ilk günüdür, Thorin Meşekalkan tarafından "güzün son mehtabının gökyüzünde güneşle birlikte olduğu gün” diye tarif edilir (Tolkien, 2007: 80). Bu listeye daha pek çok şölen ilave etmek mümkün. Açık olan, Tolkien evreninde pek çok kutlamanın yapıldığı ve birçok şölenin düzenlendiğidir. Bu kutlamaların ve şölenlerin pek çoğu, henüz Aman günlerinden başlamak üzere, şehirlerden uzaktaki sayfiye alanlarında yapılmalarıyla dikkat çeker: Númenorluların zikrettiğim üç bayramı da şehrin yanındaki kutsal sayılan dağa tırmanma ritüelini içerir, Güneşin Kapıları şenliğinde Gondolin sokakları boşalır, Mereth-Aderthad Narog Nehri'nin doğduğu yeşillik alanda kutlanır, Manwë'nin festivali onun dağın zirvesindeki evinde gerçekleşir. Bu bağlamda Tolkien evrenindeki çoğu şölenin yapılış şekli yukarıda şölen endişesinin kökenlerinden biri olarak saydığım “güvenlik eksikliği” endişesini duyumsatacak ölçüde tekinsiz sayılabilir.

Nitekim gerek onun şehirlerin büsbütün boş bırakılmasını gerektiren şölenleri ve gerekse Dede Korkut Kitabı'ndaki içki ile uykunun eşlik ettiği toylar çoğunlukla bir felakete gebe olarak karşımıza çıkarlar. ${ }^{7}$ Örneğin Dede Korkut Kitabı'nda Kanturalı'nın Selcen Hatun ile beraber yiyip içtiği şölenden sonra uyumasından bahisle "O zamanda Oğuz beylerine ne kaza gelse uykudan gelirdi.” (Gökyay, 1975: 149) şeklinde bir cümle geçer. Köse (2020: 5-9),

\footnotetext{
${ }^{7}$ Elbette istisnalar mevcuttur ve Kitâb-ı Dedem Korkud'da yer alan tüm toylar felaketle sonuçlanmaz. Şölen ritüeli aynı zamanda evrendeki düzenin yeniden yerli yerine oturmasını da simgeler. Nitekim uzun maceralar sonucunda ordasını, soyunu ve hazinesini kurtarmayı başaran Kazan Han her şeyin aslî hâline dönmesinin şerefine büyük bir toy tertip eder (Gökyay, 1975: 46).
} 
Dede Korkut Kitabı'nın Buğaç Han'a dair ilk öyküsündeki toy başlangıcını ve şölenlerdeki içki kullanımına vurgu yapılmasını "kaos ortamına giden duruma işaret etmesi” üzerinden okur. Köse'nin makalesinde incelediği kaoskozmos dengesinin işaretleyicileri Dede Korkut Kitabı'nda ve Silmarillion'da bu yönüyle bir paralellik içindedirler. Benzer şekilde, şölene katılıp enerji harcayan, içki içen ve nihayet ağır bir uykuya dalan kahramanın başına bir felaketin gelmesi Tolkien'de de görülür. Henüz Günlerin Başlangıcı'nda Valar'ın Eru'nun görevlendirmesiyle Arda'yı, yeryüzünü yaratmasından sonra onların başı sayılabilecek olan Manwë büyük bir şölen düzenler. Ileride "Arda Baharı" olarak adlandırılacak bu şölende Tulkas uyuyakalır ve Melkor bu durumdan istifade ederek Utomno ismini verdiği kalesini inşa eder. Bu ise, açıkça kozmosun kaosa doğru evirilmesine, yeryüzünün ilk tasarlanmış hâlinin bozulmasına ve bir daha aslî güzelliğine erişememesine sebep olur (Tolkien, 2020b: 85-87). Görülüyor ki Tolkien mitolojisinde şölen yeryüzündeki uyumu zedeleyecek ölçüde vahim biçimde sonuçlanabilmektedir ve Tulkas'a da tıpkı Kanturalı gibi, "ne kaza gelse uykudan gelmekte”dir. Kuşkusuz şölen endişesi bağlamındaki bu nevi paralellikleri artırmak mümkündür. Ben bu yazıda her iki metinden ikişer öyküyü karşılaştırmalı olarak okuma niyetindeyim.

\section{Işığın Kaybı Bağlamında Şölen Endişesi: Kararan Valinor ve Esir Alınan}

\section{Oğul}

Dede Korkut Kitabı'nın ikinci öyküsü olan “Salur Kazanın Evinin Yağmalandığı Boyu" canlı bir şölen tasviriyle başlar:

Doksan başlı ban evlerini kara yerin üzerine diktirmişti. Doksan yerde ala halı ipek seccade döşemişti. Seksen yerde badyalar kurulmuştu. Altın ayak sürahiler dizilmişti. Dokuz kara gözlü, güzel yüzlü, saçları ardına örülü, göğsü kızıl düğmeli, elleri bileğinden kınalı, parmakları nigârlı, sevimli kâfir kızları soylu Oğuz beylerine sağrak sürüp içerlerdi. İçip içip Ulaş-oğlu Salur Kazan'ın aklına şarabın itisi çıktı (Gökyay, 1975: 21).

Bu canlı şölen tasvirinin ${ }^{8}$ Salur Kazan'ın konuşmaya başlamadan önceki son cümlesi okura ileride neler olacağına dair bir önsezi vermiş olabilir. Anlaşıldığı gibi bu geniş ziyafetten sonra Salur Kazan'ın aklına “şarabın itisi çık-

\footnotetext{
${ }^{8}$ Dede Korkut Kitabı'nın ilk iki öyküsünü yapısalcı bir yaklaşımla renkler üzerinden analiz eden Karabaş, Salur Kazan'ın şöleninin tasvir edildiği bu anlatı biriminde beş düz ve bir karışık rengin zikredilmiş olmasının Türk toplumunun "büyük bir olgunluk içinde" olduğunu fakat "olgunlaşmanın henüz bitmediği”ni simgelediğini yazmaktadır (Karabaş, 1996: 31).
} 
mış”, yani sarhoş olmuştur. Şölen vermenin mümkün kıldığı bu sarhoşluğun etkisiyle bütün beyleriyle birlikte ava çıkmayı önerir:

Ünüm anlayın beyler, sözüm dinleyin beyler. Yata yata yanımız ağrıdı, dura dura belimiz kurudu. Yürüyelim a beyler, av avlayalım, kuş kuşlayalım, sığın geyik yıkalım, dönelim otağımıza düşelim, yiyelim, içelim, hoş vakit geçirelim (Gökyay, 1975: 21).

Görüldüğü üzere Salur Kazan bu av partisini verdiği şölenin etkisini artırmak için tasarlamışa benzemektedir. Sarhoşluğunun etkisiyle "daha fazla eğlenme" arzusuna kapılan Salur Kazan, şöleni bir "av avlama, kuş kuşlama" etkinliğiyle süslemek ve ardından kaldığı yerden eğlenceye devam edilmesi isteğindedir. Böylece Han Kazan, oğlu Uruz'la beraber birtakım erkekleri yurdunda bıraktıktan sonra bütün diğer büyük beyleriyle beraber ava çıkmaya karar verir. Dede Korkut bu ava katılan beylerin çokluğunu vurgulamak için "sayıp gitsem tükenmez" der (Gökyay, 1975: 22). Fakat şölen uğursuzluğunu beraberinde getirir: "Kâfirin casusu casuslamış"tır. Yedi bin askerle birlikte Salur Kazan'ın yurduna varırlar ve obasını esir alırlar. Şölen ve şölenin sarhoşluğu "sası dinli Gürcistan ağzında oturduğu" konusunda uyarılmasına rağmen Salur Kazan'ın uzgörüsüz davranmasına ve bunun sonucunda obasının esir olmasına sebep olmuştur. Öte yandan Karabaş (1996: 23), konuya öykünün kendi anlatım perspektifinden yaklaşarak "ikinci anlatım birimindeki” bu şölen tasvirinde Salur Kazan'ın “kişisel ün kazanma ile kendi değerini elinden geldiğince yükseltme uğruna toplumsal yaşamın doğal akışını bozan" bir portre olarak inşa edildiğini yazmaktadır.

Benzer şekilde, Tolkien'in Silmarillion'unun başlangıç kısımlarında sayılabilecek bir bölümünde, "Valinor'un Kararışına Dair" anlatıda da bir şölen ve bir kayıpla karşılaşırız. Eldar'ın doğuya gidişinden evvelki kutlu zamanlarda geçen bu hikâye, birtakım uğraşlardan sonra Melkor'un Valinor'dan uzaklaştırıldığı devreyi takip eder. Bu karanlık gücün gölgesinden sıyrılmış olan Valinor'da ise geleneksel bir şölen günü yaklaşmaktadır:

(...) Yavanna, Valinor'da büyüyüp yetişen her şeyin çiçeklenip olgunlaşacağı zamanları belirlemişti ve meyvelerin toplandığı ilk hasat dönemlerinde, Valinor'un tüm halklarının Taniquetil üzerinde neşelerini müziğe ve şarkılara kattıkları o vakitlerde, Eru'ya şükretmek, onu övmek için büyük bir şölen düzenlenirdi. İşte bu şölenin vakti geldi çattı ve Manwë bu seferki şölenin, Eldar'ın Aman'a gelişinden bu yana görülmemiş derecede ihtişamlı olması buyurdu. (...) kederin bir kenara bırakılıp Düşman'ın yalanlarının hafıza- 
lardan silinmesi için herkes Manwë'nin Taniquetil üzerindeki evine davet edilmişti (Tolkien, 2020b: 166).

Görüldüğü kadarıyla bir hasat şenliği olan bu gün Elflerin bilgelik dolu, meditatif kutlamalarından farklı olarak şarkıların söylendiği, neşe içinde eğlendikleri bir bayramdır. Üstelik Manwë, her ne kadar bir Vala olmasının kendisine kattığı engin irfanı sayesinde Melkor'un gidişinin nihaî bir zafer olmadığının bilincindeyse de onun Ilúvatar Çocukları'nın üzerindeki tesirini kırmak için bu kutlamayı faydalı bulur ve gelmiş geçmiş en görkemli kutlama olması emrini verir. Davete Finwë ile Formenos'taki diğer Noldor dışında herkes katıır. Fakat şölen Manwë'nin Taniquetil Dağı'nın zirvesindeki evinde gerçekleşeceği için bu durum Valmar'ın boşaltılması anlamına gelmektedir. ${ }^{9}$ Nitekim şölen oldukça güzel geçer, şarkılar söylenir, ziyafet verilir. Fëanor'un şölen elbiseleri giymeksizin davete katılması ve kardeşi Fingolfin ile açıkça gönülsüz bir biçimde barışması dışında şölene gölge düşüren bir şey yaşanmaz. Tabii, o sıralarda bu bayram kutlamasından haberi olan Melkor - "Melkor'un da gayet iyi bildiği gibi, bayram zamanıydı o vakitler."- ve kara gölgeler içindeki yaveri Ungoliant'ın Valinor'un iki Ağacı'na gitgide yaklaştıklarından haberdar değildirler. Tolkien, şölen devam ederken Ağaçların yanına kolayca varmayı başaran Melkor'un ve hizmetkârının yaptıklarını şöyle anlatır:

Derler ki Fëanor ve Fingolfin henüz Manwë'nin huzurunda iken, her iki Ağacın da ışıldadığı anda birbirine karıştı ışıklar ve sessiz Valmar şehri gümüş ve altın rengi bir parıltıya boğuldu. Tam o saatte işte, Melkor ve Ungoliant, Valinor'un tarlaları üzerinde, rüzgarın tepesine binip de güneşin ısıttığı toprağı yalayıp geçen kara bir bulutun gölgesi gibi hızla geçtiler ve Ezellohar'ın tepesinin önüne geldiler. Ardından Ungoliant'ın Işıksızlığı yükselip ta Ağaçların köklerine kadar vardı ve Melkor tepeciğin üzerine zıplayıp, kara mızrağı ile her birinin yüreğine darbeler indirdi ve her ikisinde de derin yaralar açtı; usareleri kan misali akıp toprağın üzerine döküldü. Ama Ungoliant bunları emdi sonuna kadar; sonra da bir o Ağaca, bir diğerine gidip gelerek, kara gagasıyla yaralarını kurutana kadar dadandı ve içindeki Ölüm zehri, dokularına kadar işleyip köklerini, dallarını ve yapraklarını soldurdu ve ölüp gittiler (Tolkien, 2020b: 168-169).

\footnotetext{
9 Valinor'un ve dolayısıyla şölenin düzenlendiği Taniquetil dağı ve bu dağın zirvesindeki Manwë'nin evinin coğrafî anlatımı ve bir haritası için bk. (Fonstad, 1979: 22-23).
} 
Böylece Manwë'nin Eru'ya şükranlarını sunmak için evinde tertiplediği şölen evrenlerinin aydınlatılmasını sağlayan iki Ağacın Melkor tarafından yok edilmesiyle son bulur. Salur Kazan "göz aydınlığı” oğlunu, Ilúvatar Çocukları ise "dünyalarını aydınlatan" ağaçlarını yitirmişlerdir. Sözün burasında ağaç motifinin eski Türkler için soyun, sülalenin simgesi sayıldığını hatırlamak ilginç olabilir (Esin, 2001: 170). Ağacın bu simgeselliğinin Türkistan'dan çıkış sonrasında da uzun süre boyunca devam ettiğini anlamamızı sağlayan çeşitli örneklere sahibiz. Örneğin Tepegöz'le mücadele ettiği Dede Korkut hikâyesinde Basat'ın ağaç simgesini yine soya ilişkin bir cümlede kullandığını görüyoruz: "Atamın adını sorarsan kaba ağaç!” (Gökyay, 1975: 184). Osman Bey'in "hemân göbegünden bir agac bitüb 'âlemi tutub ve anun gölgesinde tağlar var" şeklindeki meşhur rüyasında da ağaç, Edebalı tarafından Osman'ın kendisine saltanat verilen evladı olarak yorumlanmıştır (Neşrî, 1995: 83). Dolayısıyla, Valinor'un Ağaçlarının yitiminin Salur Kazan'ın sembolik dünyasının dilindeki karşılığı sülalenin, soyun yitimi demek olacaktır. Nitekim Salur Kazan'ın yitirdiği de soyunun devamını sağlayacak olan oğlu ve varisidir.

ilginç olan bir diğer nokta Salur Kazan'ın ava çıkıp da oğluyla beraber yurdunda bıraktıklarının baskın yiyerek esir alındıkları gece gördüğü rüyanın içeriğiyle Melkor'un Valinor'un İki Ağacı'nı kestikten sonra ortaya çıkan durum arasındaki benzerliktir. Salur Kazan oğlunun esir alındığı gece gerçekten de "kara kaygılı" bir düş görmüştür. Çırpınan bir şahinin kuşunu kaptığını, gökten yıldırımlar düştüğünü gördükten sonra rüyasını anlatmaya şu şekilde devam eder:

Tüm kara pusarık ordamın üzerine dökülür gördüm; kuduz kurtlar evime dalar gördüm; kara deve ensemden kavrar gördüm; kargı gibi kara saçım uzanır gördüm; uzanıp gözümü örter gördüm (Gökyay, 1975: 26).

Görüldüğü üzere Salur Kazan'ın düşü tümden karanlıktır. Bu düşte kör, gözün gözü görmesine imkân tanımayan bir sis yurduna çöker. Kara deve ensesinden kavrar. Kara saçı uzar ve gözünü kapatarak onu da karanlık içinde bırakır. Oğlunun esir alındığını hissederek gördüğü bu düş "gözünün nuru”nun yitmesini, ışığının sönmesini, yurdunun karanlığına gömülmesini sembolize etmektedir. Karabaş da (1996: 28) bu rüyadaki baskın siyah rengin "kötü haber, kötülük ve yıkım” ifade ettiğini söyler. Bunlar, ỉki Ağacın, Telperion ve Laurelin'in Melkor ve Ungoliant iş birliğiyle yok edilmesinin ardından Valinor'un düştüğü durum ile, yani "kararış”ın kendisiyle paraleldir: "Işık yenildi ve soldu, fakat arkasından gelen Karanlık, kaybolan ışıktan çok- 
tu. Öyle bir Karanlık oluştu ki o saatte, tek bir eksiği yok gibi görünüyordu, kendisine ait tek bir şey dışında" (Tolkien, 2020b: 169). Hatta tespit edebildiğim kadarıyla benzerlik yalnızca karanlığa ilişkin benzetmelerden ibaret değildir. Tolkien'in, oğlu tarafından bir araya getirilinceye değin yayımlanmayacak başka bir metninde, "Noldoli'nin Valinor'dan Göçmesi” başlığını taşıyan şiirinde karşımıza çıkan daha kuvvetli bir benzerlik de var. Bu şiir Melkor tarafından yok edilen Ağaçlara yakılan bir ağıtla açıır. Güneşten daha görkemli, aydan daha büyülü olarak tasvir edilen íki Ağacın Morgoth ve Ungoliant tarafından yok edilişi hatırlanır; ağaçların kararan dallarından, düşen yapraklarından bahsedilir ve nihayetinde Tolkien Ağaçların yok edilmesiyle birlikte Manwë'nin salonlarında "karanlığın sisleri”nin dolaştığını yazar (Tolkien, 1994: 159). Karanlığın sisleri -bu tabir, Salur Kazan'ın düşünde gördüğünden bahsettiği "kara pusarık"ın birebir tercümesi sayılabilir.

\section{Ceza Günü Olarak Şölen: Turgon'un Gondolin'i, Dumrul'un Köprüsü}

Ele almak istediğim diğer bir öykü ikilisini ise Gondolin'in düşüşüne dair Tolkien'in anlatısı ile Dede Korkut Kitabı'nın meşhur Deli Dumrul hikâyesi oluşturuyor. Bu sefer önceliği Tolkien'e tanımak niyetindeyim. Zira onun Gondolin'in Melkor orduları tarafından keşfedilip ele geçirilmesine dair hikâyesinin anlaşılması için daha uzun bir yolculuğa çıkmamız ve ilgili şehrin yıkımına yol açan olayları daha öncesinden takip etmemiz gerekiyor.

Gondolin -ve yedi başka isme de sahip- şehrin hikâyesinin başlangıcı Batı topraklarından göç eden Eldar'ın soylularından olan Fingolfin'in oğlu Turgon'un, Ulmo'nun inayetiyle saklı Tumladen Vadisi'ni görmesiyle başlar. Gördüğü vadi Turgon'a vatanı olan Tirion'u hatırlatır ve yurt hasretiyle bu güzel vadide Tirion'un bir benzerini inşa etmek ister. Nitekim bu arzunun kendisi de kalbine Ulmo tarafından ilham edilmiştir. Böylelikle Turgon, saklı vadide büyük bir gizlilikle yürütülen şehrin inşasına başlar (Tolkien, 1995: 40). Elli iki yıl süren bu gizli inşa sürecinden sonra Gondolin şehri, Birinci Çağ'ın 116. yılında kurulmuş olur. Turgon, halkına yol hazırlıklarına başlamalarını buyurur. Bu sırada Ulmo ona görünerek şunları söyler:

Nihayet Gondolin'e gideceksin Turgon ve ben kudretimi Sirion Vadisi'nden ve oradaki nehirlerden, derelerden eksik etmeyeceğim ki kimse gidişinin farkına varmasın yahut senin iznin ve kabulün dışında kimseler gizli geçidi bulamasın. Tüm Eldalië ülkeleri içinde, Melkor'un karşısında en uzun ömürlüsü olacak Gondolin. Lâkin elinin işine de, yüreğinin tasarladıklarına da haddinden fazla kaptır- 
ma gönlünü ve Noldor'un esas umudunun Batı'da olduğunu ve Deniz'den geldiğini unutma (Tolkien, 2020b: 272).

Ulmo'nun bu ikazının can alıcı noktası kurulması için Turgon'u yönlendirdiği şehre bağlanmaktan onu menetmesidir. Zira Noldor halkının esas umudu Batı'da, yani Valar'ın yaşadığı, göçten sonra Elfler için "mutlak-öte" halini almış "En-Batı" (Tolkien, 1965: 321) topraklarındadır. Ulmo bu ikazını günü geldiğinde unutmaması için Turgon'un bazı eşyalarını Nevrast'taki sarayında bırakmasını emreder ve böylece kendisine bu emanetlerle gelecek kişinin sözüne güvenmesini güvence altına almak ister. Ardından Turgon'un ikincil yaratıcılar olmaları bakımından ilahî bir hüviyet taşıyan Valar'ın temsilcilerinden biri olan Ulmo'nun ilhamıyla inşasına başladığı şehre yine onun ikazları ve yardımları eşliğinde yola koyulmasının zamanı gelir:

(...) ve bölük bölük yürüdüler, gizlice, Eryd Wethion gölgeleri altında ve nihayet kimseye görünmeksizin eşleri ve eşyalarıyla Gondolin'e vardılar ve hiç kimse nereye gittiklerini öğrenemedi. Hepsinden sonra da Turgon, ailesi ve lordlarıla birlikte sessizce tepelere doğru ilerledi ve dağın geçitlerini aştı ve o geçtikten sonra bütün geçitler kapandı. Ama Nivrost ıssız kalmıştı ve Beleriand'ın çöküşüne değin öyle kalmaya devam edecekti (Tolkien, 1995: 45).

Böylece Turgon ve halkı Nevrast'tan ayrılarak saklı şehir Gondolin'de ikamet etmeye başlarlar. Korunaklı duvarların ardında, Orta Dünya sakinlerinin hiçbirinin -en önemlisi o dünyanın her bir parçasını karanlığa gömmeyi amaçlayan Melkor'un- yerini bilmediği eşsiz güzellikteki şehirlerinde yaşamaya koyulurlar. Günler geçtikçe Gondolin daha da bayındır hâle gelir, çeşitli elflerin kolektif çalışmaları sonucunda ilim ve irfanda olduğu kadar zanaatkârlıkta da bir hayli gelişirler, dış dünyayla Kartallar dışında bir bağlantıları yoktur, şehirden kimsenin çıkmasına da -Aredhel gibi istisnaî örnekler hariç- izin verilmemektedir. Turgon bu gönenmiş, saklı krallıkta yüzyıllar boyu hüküm sürer. Fakat bu içe kapanık, müreffeh yaşam tarzı da Gondolinlilerde gözle görülür birtakım karakter değişikliklerine yol açmışa benzer. Zira Ulmo'nun uyarısı hafızalardan çıkmıştır. Fakat her ne kadar hafızalardan çıkmış olsa da hatırlatılmasının zamanı da gelmiştir. Ulmo ikazının gününün geldiğine kanaat getirerek Huor oğlu Tuor'u Nevrast'tan ayrılırken Turgon'un bıraktığı emanetleri yanına alarak saklı şehir Gondolin'e varmak ve Kral'ı şehri terk etmeleri konusunda uyarmak ile görevlendirir. Tuor, refakatçisi Voronwë ile birlikte uzun bir maceradan sonra yedi isimli Gondolin'e giden yedi kapılı gizli geçidi bularak Turgon'un huzuruna çıkar (Tolkien, 2020a: 78-87). Turgon, karşısına Nevrast’ta bıraktığı emanetleri ile çıkan bu 
insanın Ulmo'nun habercisi olduğunu kavrar ve Gondolin'i terk etmesinin zamanı geldiğini fark eder. Fakat Ulmo'nun uyarısı da bütün diğer uyarılar gibi tam da endişe edilen muhtemel davranış hakkındadır ve Turgon uzun uzadıya bir iç muhasebeden sonra bu kudretli Vala'nın endişe ettiği biçimde hareket etmeye karar verir - elinin işine gönlünü kaptırmıştır. Hatta enikonu karakter zaafı göstermeye bile başlamıştır: "Ama Turgon zaman geçtikçe kibirlenmişti. Gondolin, Elflerin Tirion'u kadar güzelleşip onu andırır olmuştu; bir Vala'nın tersini söylemesine karşın, şehrinin gizli ve karşı koyulmaz gücüne yine de güveniyordu" (Tolkien, 2020b: 500).

Böylelikle kendi eliyle kurduğu, yüzyıllar içinde güzelleştirdiği, emek sarf ettiği ve "Túna üzerindeki Tirion" olduğuna inandığı Gondolin'i terk etmeyen Turgon, şehrinin ve şehriyle beraber halkının felâketini de hazırlamış olur. Çeşitli vesilelerle şehrin yönünü tespit etmeyi başaran Melkor, Turgon'un yeğeni Maeglin'in ihaneti sayesinde Gondolin'in gizli geçidini de bulmayı başarır ve ordularını saklı şehre doğru ilerletmeye başlar. Tuor'un getirdiği uyarı üzerinden yedi yıl geçtiği ve hiçbir şey olmadığı için iyiden iyiye rehavete kapılan Gondolin halkı ise bu sıralarda yüksek duvarların üzerine çıkmış, yönlerini doğuya çevirmiş, güneşin doğuşunu bekliyorlar ve şarkılar söylüyorlardır. Çünkü takvimleri "Güneşin Kapıları” adını verdikleri bir şölen zamanını göstermektedir. Fakat karşılarında tanın değil, öfkeli Melkor ordularının kızıllığını bulmuşlar ve bu kızıllık "doğudan değil, kuzeyden yükselerek" Gondolin'in duvarlarının tam altına gelene kadar durmadan ilerlemiş ve şehri kuşatmıştır (Tolkien, 2020b: 505). Kral Turgon, Melkor ordularına karşı o zamana değin saklı kalmış fakat nihayetinde açığa çıkmış Gondolin'i savunurken şehir ahalisinin büyük çoğunluğuyla beraber ölür fakat Tuor ve yanındaki belli başlı bir grup başka bir gizli geçit bularak kurtulmayı başarırlar. Böylece Gondolin, Melkor ordularının o güne değin asla erişemedikleri gizli Elf krallığı da bir şölen vakti halkı şarkılar söylerken -tıpkı Manwë'nin şöleni sırasında dağların öte tarafındaki Teleri'nin şarkılarını andırır biçimde - kuşatılmış ve düşmüş olur.

Bu şekilde özetlenebilecek olan “Gondolin'in Düşüşü” öyküsünün yanında ise "Duha Koca Oğlu Deli Dumrul"un öyküsü durmaktadır. Dumrul'un öyküsü onun kendi kendini övdüğü birtakım büyüklenme cümleleri ile başlar. Turgon'un aksine onun büyüklenmesine sebep olan geçmişinden mahrumuz, Dede Korkut Kitabı onun bu övünç dolu hâli almasını sağlayan önceki başarılarından bahsetmez. Fakat öykü boyunca yiğitliğini pek çok defa ortaya koymasından Rûm'a ve Şam'a değin bilindiğini iddia ettiği "erliği, bahadırlığı, cılasınlığı, yiğitliği”ni (Gökyay, 1975: 122) birçok kere gösterme 
imkânı bulduğunu tahmin edebiliriz. Deli Dumrul'un böylesine şişinerek hikâyenin başlamasına sebep olduğu mekân ise meşhurdur: Köprü. Dumrul'un inşa ettiği bu köprüye bir hayli bağlı olduğu anlaşılmaktadır. Öyle ki "kuru" bir çay üzerinde olmasına, yani kullanımı için geçerli hiçbir sebep bulunmamasına rağmen herkesin buradan geçmesine yönelik anlaşılması zor bir talebi vardır. Yaptırdığı köprüyü bu denli önemser ve onun sorumluluğunu da bizzat üstüne almıştır. Bu bağlamda Turgon'un Gondolin'e duyduğu bağlıığın bir benzerini köprüsüne karşı sergiler. O da eliyle yaptığına gönlünü kaptırmıştır. Bu amaçla köprüden geçenden otuz üç akçe, geçmeyenden ise döve döve kırk akçe almaktadır. Köprüyü gören birine bunlardan başka bir seçenek tanımaz çünkü köprü o kadar önemlidir ki eşiğine gelenin onunla olumlu ya da olumsuz bir şekilde temasa girmesini talep eder. Sözün burasında Turgon'un nevadirden olmakla birlikte Gondolin'e dışarıdan gelme fırsatını yakalayanlara karşı takındığı tavır, daha doğrusu Gondolin'in yabancı biri tarafından bulunması hâlinde uygulanacak yasa akla gelir. Belli bir süreliğine Gondolin'den çıkmasına izin verilen, bu sırada Eöl isimli bir Kara Elf'le evlenen fakat onun yanında sürdürdüğü hayata daha fazla dayanamayıp oğluyla birlikte yurduna geri dönen Aredhel bu hareketiyle kendisini takip eden kocasının da Gondolin'e gelmesine yol açmış, Turgon ise ona yalnızca iki seçenek sunmuştu: Gondolin'e yerleşmek veya ölmek (Tolkien, 2020b: 296). Keza, Tuor da Gondolin'in gizli geçidinin girişinde yakalandıklarında muhafız Elemmakil, Gondolin topraklarında geçerli olan yasalardan birini, bir yabancının şehrin girişine ulaşması hâlinde "yakalandığı yerde öldürülmesine ya da tutsak alınmasına kendisini yakalayan muhafız mangasının karar vereceği” şeklindeki kanunu hatırlatmıştı (Tolkien, 2020a: 77). Anlaşılıyor ki Turgon şehrine "kimse"nin girmemesini ister, Dumrul ise köprüsünden "herkes"in geçmesini fakat ikisi de yapıtlarıyla diğer bütün insanlar arasında ilişki kuracak ölçüde onlara bağlıdırlar. Bunun muhtemel bir sebebini Saydam'ın Deli Dumrul öyküsü üzerine yaptığı önemli çalışmada bulabiliriz. Saydam, Dumrul'un öyküsünde - psikopatik bir tanı olarak narsistik kişilik bozukluğundan ziyade- narsistik bir zedelenme durumu ve göstergesi tespit eder. Bu zedelenme göstergelerinin en önemlilerinden biri de "kendilik nesnelerine yüklenen şişirilmiş beklenti"dir (Saydam, 2017: 158). Gondolin şehrinin Turgon için, köprüsünün ise Dumrul için bir "kendilik nesnesi”ne dönüştüğü her iki karakterin de bu nesnelere şişirilmiş beklentilerini yansıtmalarından bellidir. Turgon Ulmo'nun tasdikli habercisine rağmen şehri terk etmeyi reddeder, Gondolin'in "gizli ve karşı koyulmaz gücü”ne güveniyordur, daha doğrusu şehirden gizli kalmasını ve karşı koyulmaz bir 
güçle Melkor'un ordularının önünde durabilmesini beklemektedir. Dumrul ise çeşitli sebeplerden ötürü, yiğitliğini ve erliğini göstermesine imkân tanıyan kurumuş çay üzerindeki köprüsüne beklentilerini yansıtır. Üstelik her iki karakterde de narsistik zedelenme ile yaratıları arasında bağ vardır. Dumrul "köprüsünün başında" kendi kendini över, Turgon şehrinin bayındırladığı uzun asırlardan sonra "kibirli" olmuştur.

Dumrul'un öyküsünün ilerleyiş biçimi de malumdur. Yine kıymetli köprüsünün başında, mutat görevini icra ederken ölü bir yiğit ve etrafında ağlaşıp yas tutan insanları görür. Bu tüm dengesini alt üst eder. Kendisi gibi bir yiğidin ölmesi ve bunun karşısında hiçbir şey yapılamaması onu öfkeye sürükler. Delikanlının canını aldığını öğrendiği Azrail’e meydan okur: "Bre Azrail dediğiniz ne kişidir ki adamın canını alır? Ya Kadir Allah, birliğin, varlığın hakkıyçin Azrail'i benim gözüme göster! Savaşayım, çekişeyim, uğraşayım, yahşı yiğidin canını kurtarayım. Bir daha yahşi yiğidin canını almasın" (Gökyay, 1975: 123). Fakat meleğine karşı sarf edilmiş bu sözler ulu Tanrının hoşuna gitmez ve Azrail'e Dumrul'un canını almasını emreder. Bu sırada Deli Dumrul'un köprü başındaki mesai saati bitmiştir, onu kırk yiğit arkadaşıyla birlikte bir şölen sofrasında yiyip içerken görürüz. Aynı anda Azrail, Dumrul ve arkadaşlarının şölen yaptıkları hana girer, daha doğrusu sızar. Dumrul'un karşısında gözle görülür bir şekil almasına, tecessüm etmesine karşın korunaksız şölenin etrafındaki kimse onu fark etmeyi başaramamıştır. Dumrul olağan olanın olağanüstü karşısındaki hayretini soylar:

Bre ne heybetli kocasın!

Kapıcılar seni görmedi,

Çavuşlar seni duymadı,

Benim görür gözlerim görmez oldu,

Tutar benim ellerim tutmaz oldu,

Titredi ayağım elimden yere düştü,

Ağzımın içi buz gibi oldu,

Kemiklerim toz gibi oldu (Gökyay, 1975: 123).

Azrail, Dumrul'a kimliğini açıklar, meydan okumasına karşılık verir. Dumrul da yiğitlerin canını aldığını öğrendiği melekle karşı karşıya gelmekten büyük haz duyar. Hatta onu bu şartlar altında, "geniş yerde ararken dar yerde" ele geçirmekten ötürü duyduğu sevinci saklayamaz ve "deli”liğinin icabı olarak hanın kapıcılarına kapıları kapatmalarını söyledikten sonra Azrail'in üstüne atılır. Dumrul, hanı "Gondolinleştirme" peşindeye benzer. ULmo'nun Tuor vasıtasıyla yolladığı haberlere ve ikazlara rağmen şehrin kapalı kapılar ardında olmasına güvenen Turgon misali, Dumrul da az önce kimse- 
ye görünmeden içeri girmeyi başarmasıyla ve ürkütücü görünümüyle olağandışı bir varlık olduğu açığa çıkan ve kendisine de hayrette bırakan Azrail'i yenmek için kapıların kapanmasından faydalanmak ister. Fakat açıktır ki bu kapalı kapılar ne Turgon'un ne de Dumrul'un işine yarar, Melkor geçitten geçer ve Azrail bir güvercine dönüşerek pencereden kaçar.

Uyarılara karşı kulak tıkamak her iki karakterin de ortak özelliğidir. Silmarillion'da gördüğümüz kadarıyla Ulmo, Tuor vasıtasıyla ilettiği ikazına kulak asmayan Turgon'a Kartalların Efendisi Thorondor yoluyla Gondolin dışında gerçekleşen yıkımları haber verir. Nargothrond düşmüştür, Thingol ve vârisi Dior öldürülmüştür, Doriath yıkılmıştır. Fakat Turgon ısrarla bunları duymazdan gelir (Tolkien, 2020b: 501). Ne Ulmo'yu, ne onun elçisi Tuor'u, ne Thorondor'u dinler. Şehirden çıkmak istemeyişi bu uyarıların beklenen etkiyi yapmasını imkânsız kılar. Aynı şey Dumrul için de geçerlidir. Saydam, Dumrul'un yahşı yiğidin ölümü karşısında gösterdiği tavrın nedenini şu cümlelerle açıklamaktadır: "Vuruşmadan, savaşmadan, önceden uyarı almadan ölen yahşı güzel yiğit'in Azrail karşısında düşmüş olduğu çaresizlik, Dumrul için bir tehlikenin, abartılı öz-erki içinde görmek istemediği ölümün habercisi olmuştur" (Saydam, 2017: 172). Yani kurduğu şehri terk etmek istemeyen Turgon gibi Dumrul da "vücudun şehri”ni terk etmek istemez, onun için tüm göstergelere karşı kör ve sağır kesilir. Az önce güvercine dönüşüp pencereden uçan Azrail'i görmüştür fakat ilk hayret hissini atlattıktan sonra bu duruma oldukça anormal sayılabilecek bir tepki vererek doğanıyla birlikte Azrail'i avlamaya gider (Gökyay, 1975: 125). Turgon da aynı sebepten, "öz-erki içinde görmek istemediği düşüşün habercisi” oldukları için uyarılara kulak asmaz, daha doğrusu asamaz hâle gelmiştir. Biri Tanrı'nın "her doğanın öleceği” şeklindeki ezelî yargısına karşı mücadele içindedir, diğeri Ulmo'nun "zamanı geldiğinde şehirden çıkılması gerektiği” yönündeki ikazına karşı ayak direr. Nihayetinde birinin şehri Güneşin Kapıları şenliği esnasında şarkılar söylerlerken kuşatılır, diğeri kırk yiğitle beraber yiyip içmekteyken Azrail tarafından baskına uğrar ve onun peşine takılmışken "ak göğsünün üstüne konmuş" ölüm meleğinin ağırlığı altında "hırlamaya", can çekişmeye başlar. ikisi de kendilerinden çok daha kuvvetli bir gücün (Melkor-Tanrı) temsilcileriyle (Melkor'un ordusu-Tanrı'nın meleği) mücadele etmeye çalışmaktadır. Öykülerin kalanı birbirleriyle paralel seyretmezler. Gondolin yıkılır ve Turgon ölürken, Dumrul Tanrı'ya hoş gelen sözler söyleyerek Azrail'in pençesinden kendi yerine bir can bulması şartıyla halas olur ve oğullarından canlarını esirgeyen anne ve babası ölür, kendisi ise fedakâr eşiyle birlikte yüz kırk yıllık uzun bir ömürle ödüllendirilir. 


\section{Sonuç}

Tarih boyunca mitik kökenler, handiyse evrensel ölçekte yaygınlık gösteren düalist evren tasavvuru, özellikle sistemli inanışlarda tesadüf edilen zühd olgusu ve nihayet geçmiş asırlarda varlığı çok daha kuvvetli biçimde hissedilen güvenlik eksikliği gibi sebepler çok söylencede, destanda, kutsal metinde, halk hikâyesinde, atasözünde karşımıza "şölen endişesi" olarak isimlendirdiğimiz bir motifin çıkmasını sağlamıştır. Nitekim bu motif, hem mitolojik bilinç tarafından üretilen Dede Korkut hikâyelerinde hem de Tolkien'in eserlerinde kendini gösterir. Bu benzerliklerin varlık sebeplerinden birisi, Assmann'ın "hipoleptik ufuk" olarak isimlendirdiği dolaylı etkileşimdir. Bir diğeri, Kitâb-ı Dedem Korkud'u vücuda getiren mitolojik bilincin ortak motif ve arketipler diliyle konuştuğu anlatılardan bir kısmının Tolkien'in ilham aldığı kaynaklar olmasıdır. iki anlatı arasındaki benzerliklerin sebebini araştırma noktasında kolektif bir bilinçaltını varsayan Jungçu teorinin de ileride yapılacak araştırmalara katkı sunması mümkündür. Sonuçta eserinde gerek Kitab-ı Mukaddes'ten, gerek Avrupa (özellikle İskandinav) destanlarından ve gerekse tarihî kroniklerden izler bulunan Tolkien, bu anlatılarla "akraba" olarak nitelendirilebilecek bir mitik dil konuşan Dede Korkut hikâyelerindekine benzer motiflere başvurmuştur. Bu motiflerden biri de "şölen endişesi”ne ilişkin olandır.

Nitekim bu doğrultuda yapılan araştırma, anlatılar arasında şölen endişesini motifini içeren benzerlikler saptanmasını mümkün kılmıştır. Bu benzerliklere dair ilgili bulgulara kısa bir değini yapmak gerekmektedir. Ele alınan ilk öyküde Salur Kazan da Manwë de bir şölen vermektedir, her ikisinin de çok yakınlarında birer düşmanları ("sası dinli Gürcü kâfiri" ve "Melkor") vardır. Her ikisi de şölenlerini daha eğlenceli bir hâle getirmeyi (Salur Kazan "av avlayıp kuş kuşlamak”la ve Manwë "görülmemiş derecede ihtişamlı" bir kutlama olmasını emretmekle) amaçlamaktadır. Salur Kazan şölenin selâmeti için avlanmaya çıkarak "orda"sını başsız bırakırken Manwë de dağın tepesindeki evinde şölen vererek Valmar'ın ıssız kalmasına neden olur. Her ikisinin düşmanları da şöleni avantaj olarak kullanır ve hayatlarına ışık getirenleri (Salur'un - sembolik karşılı̆ı “ağaç” olan- oğlunu, Manwë'nin ise Ağaçlarını) gasp veya yok ederler ve bunun sonucu olarak da Salur Kazan düşünde karanlıklara boğulurken ("kara pusarık”) Manwë’yle beraber diğer Valar'ın ve Elflerin yaşadıkları Valinor karanlığa ("karanlığın sisleri”) gömülür. ỉki hikâyede de aynı itkilerle yola çıkan kahramanların benzer davranışlarının yol açtığı bir şölen yıkımına tanıklık ederiz. Sözün burasında karşılaştırmanın "denkleştirmeye" (Reinkowski, 2017: 90) dönmemesi adına Salur 
Kazan'ın yaşadığı trajedinin tek nedenli bir açıklamasını sunmaktan da kaçınmak gerekir. Çelik (2019: 95), Dede Korkut anlatılarından 21. yüzyıla avcı folklorundaki süreklilikleri incelediği makalesinde Salur Kazan'ın hikâyesinde trajediye sebep olan durumu "gereksiz yere ortaya konan savaşma arzusu ve yiğitlik performansı sergileme eğilimi" olarak saptar. Zikrettiğimiz üzere Karabaş da çalışmasında Salur Kazan'ın "kişisel ün kazanma” arzusunun üzerinde durmaktadır. Keza öykünün kendisi de Salur Kazan'ın sarhoşluğunu ayrıca vurgulayarak bu trajediye yol açan sebeplerden bir diğerine daha temas etmektedir.

Öte yandan, araştırmanın ana ekseninin bir diğer ayağını oluşturan öykü ikilisinde de Gondolin'in son şöleni ile Dumrul'un kırk yiğit arkadaşıyla beraber kurduğu içki şölenine kadar olan kısımlar birçok yönden benzerliklerin tespit edilmesine uygun öğeleri bünyelerinde taşır. Her iki öyküde de birer yapıt (Gondolin ve köprü), bu yapıtları onları gören herkesle ilişkilendirmeye yönelik bir tavır (Geçenden otuz üç, geçmeyenden döve döve kırk akçe almak ve şehre dışarıdan geleni bir daha çıkmamak üzere orada yerleşmek ya da ölmek arasında bırakmak), yapıtları "kendilik nesnesi" kılmalarını mümkün kılan birtakım narsistik düzensizlik göstergeleri (Hem Turgon'da hem Dumrul'da kibir) vardır. Yine her iki anlatıda da karakterler ilahî sayılabilecek ikazlara (Ulmo'nun ikazı, Tanrı'nın koymuş olduğu ölümlülük yasası) kulak asmazlar, bu ikazlar kendilerini defalarca yineledikleri hâlde (Thorondor'un getirdiği haberler ve Azrail'in güvercin şekline bürünmesi) basiretleri bağlanmışçasına tavırlarını sürdürürler ve her iki karakter de düzenledikleri şölen esnasında (Güneşin Kapıları ve Duha oğlu Dumrul'un şöleni) gafil avlanırlar.

Araştırmanın sonucunda Dede Korkut Kitabı ile Silmarillion anlatılarında yer verilen öykülerin şölen endişesi motifine yer vermelerine yol açan motivasyonel sebepler bakımından da birbirlerine yakın oldukları gözlemlenmiştir. Anlaşıldığı kadarıyla, özellikle "güvenlik endişesi” olarak adlandırdığımız gerekçe her iki anlatıdaki şölen endişesi motifini içeren kısımların en önemli sebebi olarak karşımıza çıkmaktadır. Bu durum, güvenlik endişesinin yoğun olarak yaşandığı devirlere ait olması itibariyle Dede Korkut Kitabı'nda gözlemlendiği kadar bir yönüyle Orta Çağ fantazyası olarak da değerlendirilebilecek olan Tolkien legendariumunda da doğal olarak göze çarpmaktadır. Her iki anlatının da çeşitli dinî geleneklerle kurdukları bağlantı, doğrudan ve dolaylı biçimde düalist dünya tasavvurunun da öykülerdeki şölen endişesi motifinin esas motivasyonlarından biri olmasını sağlamıştır. Bu minval üzere, biri otantik, diğeri modern birer efsanevî anlatı olarak her iki kitaptaki 
öyküler de mitik kökenlerle sıkı bir bağ kurmuşlardır. Bu bağ, şölen endişesi motifinin görünür kılınmasına etkide bulunmuştur. Araştırmada zikrettiğimiz motivasyonel sebeplerden zühd kavramının, gerek geçiş döneminin ruhunu yansıtması sebebiyle büsbütün ortodoks sayılamayacak çeşitli anlayış ve pratiklere yer veren Dede Korkut Kitabı'nda ve gerekse fantastik evreninde ruhban sınıfını anımsatacak bir gruba yer vermemesi sebebiyle Tolkien'in Silmarillion'unda şölen endişesi motifinin ortaya çıkmasına en düşük ölçüde katkı sağlayan sebep olduğu ileri sürülebilir.

Şölen endişesi motifine ilişkin olarak öyküler arasında saptanan bu benzerlikler ne söylemektedir? Bu benzerlikler en başta Assmann'ın hipoleptik ufuk olarak adlandırdığı bağın, doğrudan mitolojik bilincin ürettiği bir anlatı olan Dede Korkut hikâyeleri ile ait olduğu medeniyet dairesinin mitolojik bilinci tarafından üretilmiş anlatılardan büyük oranda etkilenmiş Tolkien metinleri arasında mevcut olduğuna dair savımıza bir dayanak oluşturmuştur. Bu da modern zamanlarda efsanevî anlatılara yaslanarak üreten yazarların yalnızca doğrudan etkilendikleri metinlerin değil, aynı zamanda o metinlerin etkileştikleri daha geniş bir mitolojik bilincin de yapıtları üzerinde tesir bıraktığı anlamına gelmektedir. Bu benzerlikler göstermektedir ki metinler arası etkileşimler yalınkat bir doğrudanlığın ötesinde, Tolkien'in “Öykü Kazanı" olarak kavramsallaştırdığı daha geniş bir havzanın evrensel sınırları dâhilinde gerçekleşmektedir. Dolayısıyla karşılaştırmalı araştırmalar oldukça bariz birtakım benzerlikler ve farklılıklar listesi oluşturmanın ötesinde, araştırmacıya daha geniş bir perspektifle çalışma imkânını sunmaktadır. Birbirlerinden çok farklı zamanlarda ve coğrafyalarda vücuda gelmiş Dede Korkut hikâyeleriyle Silmarillion arasında gerçekleştirilmiş olan bu karşılaştırmalı okuma çalışmasının bahsedilen perspektifin imkânını vurgulama noktasında bir katkı sağlayabileceği inancındayız.

Tespit edilen paralelliklerin söyledikleri bunlarla sınırlı değildir. Bu benzerlikler, Türkiye'de Dede Korkut Kitabının hakkıyla takdir edilemediğini düşündüğüm bazı yönlerini de gözler önüne sermektedir. Makalenin tartışma kısmında değindiğim gibi, Abdulla'nın haklı bir biçimde “otantik mit çağı”nın bir ürünü olarak nitelediği Dede Korkut hikâyeleri, en az mitolojik bilinç tarafından üretilmiş emsalleri kadar evrensel motifi bünyesinde taşımaktadır. Dolayısıyla Kitab-ı Dedem Korkud'u belli bir muhitin mitolojik bilincinin imzasını taşımakla beraber, adeta mukadder, dolayısıyla değişmez kabul edilen sınırların içerisine hapsetmemek gerekir. Bu öykülerden bir ideoloji kaldıracı olarak istifade edilmesi ise büsbütün yanlış olacaktır. Bu çalışmada modern bir yazar ile arasında tespit edilen benzerlikler de göstermektedir ki 
Dede Korkut hikâyeleri mitolojik açıdan otantik bir metin olması, evrensel destan ve efsane külliyatı ile ortak motifleri ve arketipleri paylaşması, kurgusal yapısı ve öyküleme şekliyle evrensel ölçekte araştırıması ve değerlendirilmesi icap eden bir metindir. Dolayısıyla Kitâb-ı Dedem Korkud'un emsalleri sayılabilecek ilyada, Kalevala, Beowulf vb. anlatılara kıyasla daha az sayıda araştırmaya daha kısıtlı bir perspektifle konu olduğu gerçeği, ancak hakkında yapılacak araştırmaların sayısının artıııması ve bu araştırmaların teorik olarak sağlam bir noktadan hareket etmelerine ilişkin bir çabayla aşılabilir gözükmektedir.

\section{Kaynakça}

Abdulla, Kamal (2020). Dede Korkut Kitabı'nın Poetikasına Giriş: Şafak Varyantı. İstanbul: Ötüken Neşriyat.

Assmann, Jan (2015). Kültürel Bellek: Eski Yüksek Kültürlerde Yazı, Hatırlama ve Politik Kimlik. Çev. Ayşe Tekin. İstanbul: Ayrıntı Yayınları.

Ateş, Süleyman (1996). Kur'ân-ı Kerîm Meâli. i̇stanbul: Yeni Ufuklar Neşriyat. Bahtin, Mihail (2001). Karnavaldan Romana: Edebiyat Teorisinden Dil Felsefesine Seçme Yazılar. Çev. Cem Soydemir. İstanbul: Ayrıntı Yayınları.

Bahtin, Mihail (2005). Rabelais ve Dünyası. Çev. Çiçek Öztek. İstanbul: Ayrıntı Yayınları.

Bergson, Henri (2015). Gülme: Komiğin Anlamı Üstüne Deneme. Çev. Yaşar Avunç. İstanbul: Ayrıntı Yayınları.

Burckhardt, Titus (2017). Doğu'da \& Batı'da Kutsal Sanat: Sanatın ilkeleri ve Yöntemleri. Çev. Tahir Uluç. İstanbul: Insan Yayınları.

Campbell, Joseph (1995). ilkel Mitoloji: Tanrı'nın Maskeleri. Çev. Kudret Emiroğlu. Ankara: İmge Kitabevi Yayınları.

Carpenter, Humphrey (1977). Tolkien: A Biography. Boston: Houghton Mifflin. Comte-Sponville, André (2004). Büyük Erdemler Risalesi. Çev. Işık Erdügen. İstanbul: İstanbul Bilgi Üniversitesi Yayınları.

Çelik, Adil (2019). "Dede Korkut Anlatılarından XXI. Yüzyıla Avcı Folklorundaki Süreklilik ve Dönüşümlerin Ekoeleştirel Bir Analizi”. Ekoeleştiri: Folklor ve Edebiyat incelemeleri. Ed. Adil Çelik ve Altuğ Ortakçı. Ankara: Kömen Yayınları, 81-105.

Eliade, Mircea (2001). Mitlerin Özellikleri. Çev. Sema Rifat. İstanbul: Om Yayınevi. 
Eliade, Mircea (2017a). Dinsel inançlar ve Düşünceler Tarihi 2: Gotama Budha'dan Hıristiyanlığın Doğuşuna. Çev. Ali Berktay. İstanbul: Alfa Yayınları.

Eliade, Mircea (2017b). Dinler Tarihine Giriş. Çev. Lale Arslan Özcan. İstanbul: Alfa Yayınları.

Elias, Norbert (2017). Uygarlık Süreci: Sosyo-Oluşumsal ve Psiko-Oluşumsal Incelemeler. Çev. Ender Ateşman. İstanbul: iletişim Yayınları.

Ergin, Muharrem (1997). Dede Korkut Kitabı. İstanbul: Boğaziçi Yayınları.

Esin, Emel (2001). Türk Kozmolojisine Giriş. İstanbul: Kabalcı Yayınları.

Fonstad, Karen W. (1979). The Atlas of Middle-Earth. Boston: Houghton Mifflin.

Gökyay, Orhan Şaik (1975). Dede Korkut Hikâyeleri. İstanbul: Kültür Bakanlığı Yayınları.

Homeros (1975). ilyada. Çev. Azra Erhat ve A. Kadir. İstanbul: Sander Yayınları.

Jaspers, Karl (1953). The Origin and Goal of History. New Haven: Yale University Press.

Karabaş, Seyfi (1996). Dede Korkut'ta Renkler. İstanbul: Yapı Kredi Yayınları. Köse, Serkan (2020). "Dede Korkut Kitabı'nı Kaos ve Kozmos Bağlamında Okuma". Milli Folklor, 125: 71-81.

Kramer, Samuel Noah (2016). Sümerler: Tarihleri, Kültürleri ve Karakterleri. Çev. Özcan Buze. İstanbul: Kabalcı Yayınları.

Kutsal Kitap: Eski ve Yeni Antlaşma (2002). İstanbul: Kitabı Mukaddes Şirketi.

Librán-Moreno, Miryam (2011). “'Byzantium, New Rome!' Goths, Langobards, and Byzantium in The Lord of the Rings". Tolkien and the Study of His Sources: Critical Essays. Ed. Jason Fisher. Jefferson: McFarland \& Co., 84-116.

Lönnrot, Elias (1966). Kalevala-Fin Destanı (Rulo 26-50). Çev. Lale Obuz ve Muammer Obuz. Ankara: Balkanoğlu Matbaacılık.

Neşrî (1995). Kitâb-ı Cihan-Nümâ. Ankara: Türk Tarih Kurumu Yayınları.

Oort, H. Van (2006). "Augustine and Manichaeism: New Discoveries, New Perspectives”. Verbum et Ecclesia, 27(2): 709-728. 
Reinkowski, Maurus (2017). Düzenin Şeyleri, Tanzimat'ın Kelimeleri: 19. Yüzyıl Osmanlı Reform Politikasının Karşılaştırmalı Bir Analizi. Çev. Ç. Canan Dikmen. İstanbul: Yapı Kredi Yayınları.

Sanders, Barry (1995). Kahkahanın Zaferi: Yıkıcı Tarih Olarak Gülme. Çev. Kemal Atakay. İstanbul: Ayrıntı Yayınları.

Saydam, M. Bilgin (2017). Deli Dumrul'un Bilinci: 'Türk-islâm Ruhu' Üzerine Bir Kültür Psikolojisi Denemesi. İstanbul: Metis Yayınları.

Shippey, Tom (2005). The Road to Middle-Earth. London: Harper Collins.

Shippey, Tom (2007) Roots and Branches: Selected Papers on Tolkien. Zollikofen: Walking Tree Publishers.

Togan, Zeki Velidi (1982). Oğuz Destanı: Reşideddin Oğuz-nâmesi, Tercüme ve Tahlili. İstanbul: Enderun Kitabevi.

Tolkien, John R. R. (1965). The Fellowship of the Ring. New York: Ballantine Books.

Tolkien, John R. R. (1981). The Letters of J. R. R. Tolkien. Eds. Christopher Tolkien \& Humphrey Carpenter. Boston: Houghton Mifflin.

Tolkien, John R. R. (1994). The History of Middle-Earth III: The Lays of Beleriand. Ed. Christopher Tolkien. New York: Del Rey Books.

Tolkien, John R. R. (1995). The History of Middle-Earth XI: The War of the Jewels. Ed. Christopher Tolkien. London: Harper Collins.

Tolkien, John R. R. (2007). Hobbit. Çev. Gamze Sarı. İstanbul: ithaki Yayınları.

Tolkien, John R. R. (2008). On Fairy-stories. London: Harper Collins.

Tolkien, John R. R. (2020a). Bitmemiş Öyküler. Çev. Kemal Baran Özbek. İstanbul: Ithaki Yayınları.

Tolkien, John R. R. (2020b). Silmarillion. Çev. Berna Akkıyal. İstanbul: ithaki Yayınları.

Ülken, Hilmi Ziya (2017). Anadolu Kültürü Üzerine Makaleler. Ankara: Doğu Batı Yayınları.

Vigarello, Georges (1996). Temiz ve Kirli: Ortaçağ’dan Günümüze Vücut Bakımının Tarihi. Çev. Z. Zühre ilkgelen. İstanbul: Kabalcı Yayınevi.

Xun, Bi (2000). "Dede Korkut Kitabı'nın Şamanlık Temeli”. Çev. Alimcan inayet. Türk Dünyası Dil ve Edebiyat Dergisi, 10: 465-481.

Yılmaz, Hüseyin (2007). Budist Metafiziği. Ankara: Hece Yayınları. 
"COPE-Dergi Editörleri iç̧in Davranış Kuralları ve En İyi Uygulama ilkeleri” çerçevesinde aşağıdaki beyanlara yer verilmiştir:

Etik Kurul Belgesi: Bu çalışma için etik kurul belgesi gerekmemektedir.

Çıkar Çatışması Beyanı: Bu makalenin araştırması, yazarlığı veya yayınlanmasıyla ilgili olarak yazarın potansiyel bir çıkar çatışması yoktur.

The following statements are made in the framework of "COPE-Code of Conduct and Best Practices Guidelines for Journal Editors":

Ethics Committee Approval: Ethics committee approval is not required for this study.

Declaration of Conflicting Interests: The author has no potential conflict of interest regarding research, authorship or publication of this article. 